\title{
アセアン諸国のメニエール病
}

第 1 報

北原 正章・児玉 章

\section{Meniere's Disease in Asean Countries}

Masaaki Kitahara, Akira Kodama

Department of Otolaryngology, Shiga University of Medical Science

In 1992, responses to a questionnaire on Meniere's disease were obtained from 39 Asean doctors. 1) Meniere's disease is not so rare in Asean countries. However, symptoms seemed less severe than in Japan or western countries. 2) Most Meniere's patients did not smoke or drink alcohol. 3) Meniere's patient seemed to occur more frequently in females than in males.

Key words: Meniere's disease, Asean, epidemiology

\section{はじめに}

メニエール病の有病率や病像の人種や環境によ る変化を検討することは，この疾患の成因を明ら かにする上で重要な命題だが, 診断基準の相違, 有病率, 受診率が複雑に絡み合って真実は必ずし あ明らかでない。筆者は1967年, 京都大学耳鼻咽 喉科並びにルイジアナ州立大学耳鼻咽喉科でメ二 エール病調查を行い白人・アメリカンニグロ・日 本人間のメニエール病病像を比較した1)。わが国 の経済成長以前のこの時期の調查で,メニエール 病は白人に激しく日本人に穏やかであったが，こ れは主として環境要因によると考えられ，人種に よる相違はメ二エール病の有病率にも見られなか った。

ところで, わが国では1974年以来メニエール病 は特定疾患の 1 つに数えられ詳細な疫学調査む行 われるようになったが，アセアン諸国ではメ二エ 一ル病の学術報告さえ見られない。そこで筆者は 1992年12月，国立インドネシア大学医学部耳鼻咽

滋賀医科大学耳鼻咽喉科学教室
喉科 (主任イスカンダール教授)，国立マレーシア 大学医学部耳鼻咽喉科（主任ロックマン博士）の 協力を得て，雨国におけるメ二エール病の実態を 調查することとした。今回は第 1 報を報告する。

\section{調查方法}

インドネシアでは1992年12月6日ジャカルタで メニエール病シンポジゥムが, マレーシアでは同 年12月 8 日クアラルンプールでマレーシア耳鼻咽 喉科学会が開催された折, 筆者は厚生省前庭異常 調查研究班によるメ二エール病の診断基準 分説明した上で表 1 に示した質問表に対する各医 師の日常診療から得た印象を求めた。表 2 は対象 とした医師を示す。

\section{結 果}

以下，各表左端に示す事項を経験したか, また はその事項に同意した医師の数を示す。

表 3 はもっともメニエール病を診療する可能性 のある診療科を示す。

表 4 はメニエール病経験の有無, 頻度を示す。 表 5 はメ二エール病患者の性，年齢を示す。 表 6 はメニエール病患者の居住地, 経済状態, 
Your name

What is your speciality? $\square$ otolaryngologist, $\square$ Internist, $\square$ Neurologist, $\square$ Psychiatrist, $\square$ Genexal, $\square$ others You are working at $\square$ university hospital, $\square$ general hospital, $\square$ private office, $\square$ others.

How many patients (any disease) do you see a month?

(or week?

Mainly, which specialist in your country see Meniere's patients? $\square$ otolaryngologists, $\square$ Internists, $\square$ Neurologists,

$\square$ Psychiatrists, $\square$ General, $\square$ others.

Have you ever seen Meniere's patients(s)? $\square$ yes, $\square$ no.

F IF YES, PLEASE ANSWER THE FOLLOWING QUESTIONS:

How many Meniere's patients do you see a month?

lor week?

Your Meniere's patients sex? $\square$ mainly male, $\square$ mainly female, $\square$ hard to say which.

What age group were most of your Meniere's patients?

$\square-20, \square$ 20-30, $\square$ 30-50, $\square$ 20-60, $\square$ 60-

$\square$ hard to say which.

Where were most of your Meniere's patients' living?

$\square$ in country side, $\square$ in a large city,

$\square$ haxd to say which.

What were your Meniere's patients' occupations?

$\square$ brain worker(white collar), $\square$ physical labor(blue collar)

What were youx Meniere's patients' economical conditions?

$\square$ xich, $\square$ poox, $\square$ hard to say which.

What were most of your Meniere's patients' habits?

$\square$ smoker; $\square$ non smoker, $\square$ drinker, $\square$ non drinker.
Did any of your meniere's patients come from families where other members suffered the same disease? $\square$ yes, $\square$ no.

Did your Meniere's patients suffer any accompanied complications?

$$
\square \text { yes, } \square \text { no. }
$$

IF YES, what were they? $\square$ low blood pressure,

$\square$ high blood pressure, $\square$ diabetes, $\square$ otitis media.

$\square$ allergy, $\square$ tuberculosis, $\square$ syphilis, $\square$ others

What was the average frequency of attack of your Meniere's patients?

$\square$ daily, $\square$ weekly, $\square$ monthly, $\square$ yerly,

$\square$ once per several year, $\square$ hard to say.

What was the average duration of your Meniere's patients attacks?

$\square$ less than 10 minutes, $\square$ 10-60 minutes, $\square$ 1-5 hours,

$\square$ 5-10 hours, $\square$ more than 10 hours, $\square$ hard to say.

What was the average lapse of time between your patients first attack and his (her) visit to you? $\square-1$ year, $\square$ 2-5 years,

$\square$ 5-10 years, $\square$ 10-20 years, $\square$ 20-years,

$\square$ hard to answer.

Do you feel that all of your Meniere's patients were easily treatable? $\square$ yes, $\square$ no, $\square$ hard to say.

Have you ever had experience with severe Meniere's patients?

$\square$ yes, $\square$ no.

IF YES, what is the percentage of your severe Meniere's patients out of all of your Meniere's patients? about

What were chief complaints? $\square$ bilateral deafness, $\square$ deafness,

$\square$ tinnitus, $\square$ dizziness, $\square$ others

Have you ever had experience with Meniere's patients who could not work at least one month because of this disease. $\square$ yes, $\square$ no.

Thank you very much for your kind help! 
表 2 回答を寄せたアセアンの医所

\begin{tabular}{|c|c|c|c|c|}
\hline & & アセアン & インドネシア & マレーシア \\
\hline \multirow{3}{*}{ 専 } & 耳鼻咽喉科 & 32 & 7 & 25 \\
\hline & 神 経 科 & 1 & 1 & - \\
\hline & 内 & - & - & - \\
\hline \multirow[t]{2}{*}{ 阴 } & - & 5 & 5 & 一 \\
\hline & そ の 他 & 2 & - & 2 \\
\hline \multirow[b]{2}{*}{ 勤 } & 大学病院 & 20 & 5 & 15 \\
\hline & 市中病院 & 12 & 2 & 10 \\
\hline \multirow[t]{2}{*}{ 務 } & 開 & 3 & 2 & 1 \\
\hline & そ の 他 & 2 & 2 & - \\
\hline
\end{tabular}

表 3 メニエール病を主としてみる診療科

\begin{tabular}{|c|c|c|c|}
\hline & アセアン & インドネシア & マレーシア \\
\hline 耳鼻咽搌科 & $29(56)$ & 7 & 22 \\
\hline 神 経 科 & 12 & 5 & 7 \\
\hline 内 科 & 4 & 3 & 1 \\
\hline 一 般 & 7 & 3 & 4 \\
\hline
\end{tabular}

表 4 メ二エール病診療経験の有無上診療頻度

\begin{tabular}{c|c|c|c}
\hline \hline & アセアン & インドネシア & マレーシア \\
\hline 経験あり & $35 / 40(88)$ & $12 / 13(92)$ & $23 / 27(85)$ \\
\hline \multicolumn{4}{|c|}{ 外来患者に対する割合 } \\
\hline $0.01 \%$ & 1 & 1 & - \\
$0.1 \sim 1.0 \%$ & 4 & - & 4 \\
$1.0 \%$ & 15 & 6 & 6 \\
\hline
\end{tabular}

表 5 メ二エール病患者の性，年跲

\begin{tabular}{|c|c|c|c|c|}
\hline & & アセアン & インドネシア & マレーシア \\
\hline \multirow{3}{*}{ 性 } & 男 & 4 & 2 & 2 \\
\hline & 女 & 11 & 1 & 10 \\
\hline & $?$ & 20 & 9 & 11 \\
\hline \multirow{3}{*}{ 年 } & $\sim 20$ & - & $\ldots$ & - \\
\hline & $20 \sim 30$ & 1 & - & 1 \\
\hline & $30 \sim 50$ & 26 & 8 & 18 \\
\hline \multirow{3}{*}{ 令 } & $50 \sim 60$ & 5 & 3 & 2 \\
\hline & $60 \sim$ & 1 & 1 & - \\
\hline & $?$ & 2 & - & 2 \\
\hline
\end{tabular}


表 6 メニエール病患者の居住地, 経済状態, 職業

\begin{tabular}{c|c|c|c|c}
\hline \hline & & アセアン & インドネシア & マレーシア \\
\hline 居 & 都 市 & 23 & 15 & 8 \\
地 & 地 方 & - & - & - \\
\hline 経 & 良 & 13 & 9 & 4 \\
济 & 悪 & 8 & 5 & 3 \\
態 & $?$ & 1 & 1 & - \\
\hline 職 & 知能労衝 & 18 & 17 & 7 \\
業 & 肉体労働 & 12 & 11 & 4 \\
\hline
\end{tabular}

表 $7 x=エ ー ル$ 病治療の難易度, 家族内発生

\begin{tabular}{c|c|c|c}
\hline & アセアン & インドネシア & マレーシア \\
\hline 治し易い & 9 & 5 & 4 \\
治し難い & 17 & 4 & 13 \\
$?$ & 9 & 3 & 6 \\
\hline 激しい症例経験 & $11 / 36(31)$ & $4 / 13$ & $7 / 23$ \\
難聴 & 5 & 1 & 4 \\
耳鳴 & 7 & 3 & 5 \\
めまい & - & - & $6 / 22$ \\
\hline 1 力月以上 & $10 / 33(30)$ & $4 / 11$ & $1 / 21$ \\
\hline 学働不能例 & & $2 / 10$ & \\
\hline 家族内発生例 & $3 / 31(10)$ & & \\
\hline
\end{tabular}

賳業を示す。

表 7 はメニエール病患者の重症度, 家族内発生 の経験を示す。

表 8 はメニエール病発作の頻度, 発作時間, 疾 患持続を示す。

\section{考察}

アセアン諸国であメニエール病は主として内科 医または耳鼻咽喉科医を受診し，内科医を受診し た場合であ多くは最終的に耳鼻咽喉科医に紹介さ れるというから，これらの国ではメニエール病を 耳鼻咽喉科以外の診療科が診療するため，この疾 患が耳鼻咽喉科医にとって少なく見えるというこ とはなさそうであった（わが国の1988年の調査 ${ }^{3}$ ではメニエール病患者の $43 \%$ は耳鼻咽喉科医を， $67 \%$ は他の専門医を受診している)。

アセアンでは耳鼻咽喉科医の $90 \%$ がメ二エー ル病を経験しているから,メニエール病がこの地
方で稀な疾患だという事もなさそうである。ただ 外来患者に対するメニエール病患者の占める割合 は，質問が 1 週間または 1 月に何人のメ二エール 病患者を見るかという内容であったので，実際の 割合よりだいぶ多めに出た嫌いはある（わが国の 1977年調查 ${ }^{4)}$ では大学病院外来患者の $0.2 \sim 1 \%$ がメニエール病患者であった)。

性別に関しては，特に興味ある結果を得た。す なわちマレーシアでは多くの医師がメニエール病 患者は女性に多い之感じている事である。その理 由に対する回答は殆ど得られなかったが，女性は 妊婦出産などを経験するから，女性はめまいを男 性より苦痛に感ずるから等の回答があった（わが 国のメニエール病病男女比で，女性の割合は 1977 年調査 ${ }^{(2)}$ では $51 \%, 1988$ 年調查 た)。年齢に関してはわが国と同様, 壮年期後半 が多数を占めていた。 
表 $8 x=エ ー ル$ 病発作の頻度, 発作時間, 疾患持続

\begin{tabular}{c|c|c|c|c}
\hline & & アセアン & インドネシア & マレーシア \\
\hline 発 & 日 & 2 & 2 & - \\
作 & 週 & 6 & 2 & 4 \\
頻 & 月 & 9 & 2 & 7 \\
度 & 年 数年 & 4 & - & 4 \\
\hline & $?$ & 15 & 5 & 10 \\
\hline & $<10$ 分 & 6 & 2 & 4 \\
発 & $10 \sim 60$ 分 & 12 & 3 & 9 \\
作 & $1 \sim 5$ 時間 & 6 & 1 & 5 \\
時 & $5 \sim 10$ 時間 & 2 & 2 & - \\
問 & 10 時間 & 3 & 1 & 1 \\
& $?$ & 6 & 3 & 3 \\
\hline \multirow{3}{*}{ 疾 } & $<1$ 年 & $19(56)$ & 4 & 15 \\
患 & $2 \sim 5$ 年 & 2 & 1 & 1 \\
持 & $5 \sim 10$ 年 & 1 & - & 1 \\
続 & $20 \sim 20$ 年 & - & - & - \\
& 20 年 $<$ & - & - & - \\
\hline & $?$ & 12 & 6 & $(\quad \%$
\end{tabular}

患者の居住地, 経済状態，職業は医師の居住地 や受診率に大きく左右される上，この調查結果か ら屯一定の傾向は見られなかった。

メニエール病患者の契煙飲酒の習慣については, 無しとする回答が多かった。これらの国の製煙， 飲酒率統計は得られていないが，マレーシアの耳 鼻咽喉科医によると，宗教上の理由加ら飲酒しな い人むいが，マレーシアで喫煙者や飲酒者が極 めて少ない事実は無いという。なぜメ二エール病 患者に喫煙飲酒の習慣が少ないかという質問に対 する回答は殆ど得られなかった。ただメニエー ル病は女性に多いが，女性は喫煙飲酒の習慣がな いから，メ二エール病患者に飲酒喫煙の習慣が少 なく見えるとの意見や，メ二エール病は上流階級 に多いが，上流階級の人々は飲酒喫煙の習慣がな いなどの意見があった（わが国の1977年調查 ${ }^{4)}$ で はメニエール病患者の飲酒喫煙の習慣は約 $50 \%$ に見られた。しかし，この数值に対照群間で有意 差はなかった)。

この調查ではメニエール病が治瘉し易い疾患だ と考えている医師は少なかったが，メニエール病 発作頻度はさておき，発作時間を $50 \%$ の医師は 1 時間以内之答元，疾患持続も $90 \%$ の医師が 1 年
以内と答えている(わが国の1977年調査 ${ }^{4)}$ では 1 時間以内の発作は $30 \% ， 1988$ 年調査 ${ }^{3)}$ では $15 \%$ にすぎなかった。また1977年調査 ${ }^{4}$ でによると， 疾患掘続 1 年以内の症例は $9 \%$ に過ぎなかった)。 アセアン諸国のメ二エール病病像は日本のそれよ り穞やかだと思われる。

この調查は医師のメ二エール病に対する印象を 踭ねたのであって，わが国の調查と直接比較出来 ないが, 現在の日本のメ二エール病病像より穞や かであるアセアンのメニエール病も1967年の筆者 の調査 ${ }^{1}$ に上る当時の日本のメ二エール病の病像 とは良く類似している。経済成長, 機械文明の発 展に伴いメ二エール病は激しさを增してくるとの 見解は正しいと思われる。契煙飲酒の習慣がス卜 レス解消となりメニエール病発生に抑制効果があ るのか, または発生を助長するのか早急に結論ず けられない。現在, 国立インドネシヤ大学耳鼻咽 喉科ェンジェプ・ハシャールル博士と, 国立マレー シア大学ロックマン・サイム博士と共に更に詳細 なメニエール病調查プロシェクトを進めている。

Acknowledgment :

I would like to express my heartfelt appreciation and gratitude to Professor Nurbaiti 
Iskandar, M.D., Professor Hendar to Hendarmin, M.D., Masrin Munir, M.D., Entjep Hadjar, M.D., John Tan, M.D., Lokman Saim, M. D. for their Kind help in this investigation. 文 献

1) 北原正章, 他：メニエール病の人種的相違を めぐって.耳鼻臨床 $63: 1090-1094,1970$

2) Kitahara $M:$ Ceoncepts and diagnostic criteria of Meniere's disease. Meniere's Disease. pp 3-12, Springer verlag, Tokyo, 1990
3) 渡辺 勈, 他 : メ二エール病全国調查の解析. 43-47頁, 前庭異常調査研究班昭和63年度研 究報告書, 1988

4）猪 初男, 他：疫学分科会調查報告. 12-31 頁, メニエール病調查研究班昭和51年度研究 報告書, 1977

$$
\left(\begin{array}{l}
\text { 原稿到着 : 平成 } 5 \text { 年 } 4 \text { 月 } 16 \text { 日 } \\
\text { 別刷請求先 : 北原正章 } \\
\text { †520-21 滋賀県大津市瀬田月輪町 } \\
\text { 滋賀医科大学耳鼻咽喉科学教室 }
\end{array}\right)
$$

